\title{
Antileishmanial in vitro activity of essential oil from Myrciaria plinioides, a native species from Southern Brazil
}

\author{
Carla Kauffmann ${ }^{1}$, Ana Caroline Giacomin ${ }^{1}$, Kelen Arossi ${ }^{1}$, Leandra Andressa Pacheco ${ }^{1}$, Lucélia \\ Hoehne $^{2}$, Elisete Maria de Freitas ${ }^{1}$, Gérzia Maria de Carvalho Machado ${ }^{3}$, Marilene Marcuzzo do \\ Canto Cavalheiro ${ }^{3}$, Simone Cristina Baggio Gnoatto ${ }^{4}$, Eduardo Miranda Ethur ${ }^{\circledR 2, *}$
}

\author{
${ }^{I}$ Centro de Ciências Biológicas e da Saúde, University of Vale do Taquari - Univates, Lajeado, RS, Brazil, ${ }^{2}$ Centro de \\ Ciências Exatas e Tecnológicas, University of Vale do Taquari - Univates, Lajeado, RS, Brazil, ${ }^{3}$ Laboratory of Biochemistry of \\ Trypanosomatid, Institute Oswaldo Cruz (FIOCRUZ), Rio de Janeiro, RJ, Brazil, ${ }^{4}$ Faculty of Pharmacy, Federal University of \\ Rio Grande do Sul, Porto Alegre, RS, Brazil
}

\begin{abstract}
In South American folk medicine members of the genus Myrciaria are used for the treatment of malaria, diarrhoea, asthma, inflammation and post-partum uterine cleansing. The aim of this work was to evaluate its antileishmanial properties (in vitro) of essential oil derived from leaves of Myrciaria plinioides D. Legrand, a plant species that is native in South of Brazil. The essential oil was obtained by hydro-distillation using fresh leaves of M. plinioides. The chemical composition of this essential oil (MPEO, M. plinioides essential oil) was determined by gas chromatography coupled to mass spectrometry (GC-MS). MPEO was assayed in vitro for antileishmanial properties against promastigotes of Leishmania amazonensis and Leishmania infantum, and for cytotoxicity against murine peritoneal macrophages. The MPEO comprised 66 components and was rich in oxygenated sesquiterpenes $(82.66 \%)$ containing spathulenol $(21.12 \%)$ as its major constituent. The MPEO was effective against $L$. amazonensis with $\mathrm{IC}_{50}$ value of $14.16 \pm 7.40 \mu \mathrm{g} / \mathrm{mL}$, while against $L$. infantum the $\mathrm{IC}_{50}$ value was higher with $101.50 \pm 5.78 \mu \mathrm{g} / \mathrm{mL}$. The MPEO showed significant activity against L. amazonensis, and presented a selectivity index (SI) of 6.60. The results suggest that the essential oil from leaves of $M$. plinioides is a promising source for new antileishmanial agents against $L$. amazonensis.
\end{abstract}

Keywords: Antileishmanial activity. Myrciaria plinioides. Myrtaceae. Leishmania amazonensis. Leishmania infantum.

\section{INTRODUCTION}

Leishmaniasis, a parasitic infection caused by protozoa of the genus Leishmania, rates as one of the most pernicious of neglected tropical diseases. Some 350 million people worldwide are at risk of contracting one of the forms of the disease, and around 2 million new cases occur annually, mainly within the poorest populations in developing countries. Various factors have contributed to the increase in the number of cases of the disease, especially the difficulties associated with vector control and the lack of a vaccine (Freitas-Junior et al., 2012). Moreover, drugs such as meglumine antimoniate

\footnotetext{
*Correspondence: E. M. Ethur. Centro de Ciências Exatas e Tecnológicas, Universidade do Vale do Taquari - Univates. Avenida Avelino Tallini, 171, Universitário, 95900-000, Lajeado-RS, Brazil. Tel: +55 51 3714-7000 / Fax: +55 51 3714-7001. E-mail: eduardome@univates.br
}

and pentamidine isethionate that are commonly employed in the treatment of leishmaniasis are of somewhat limited application because of issues relating to routes of administration, adherence to treatment, resistance, toxicity and/or teratogenicity (Buckner, Waters, Avery, 2012).

Alternative therapies, including miltefosine and paromomycin, and new formulations of older medications such as amphotericin $\mathrm{B}$, have been introduced but most are restricted in their use and none provide a satisfactory treatment of the disease (Freitas-Junior et al., 2012). In this context, medicinal plants that have been applied in traditional remedies often represent promising sources of lead compounds for the development of new drugs (Oliveira et al., 2011). Within the last few years, considerable research interest has focused on screening plant extracts as potential sources of drugs for the treatment of leishmaniasis (Vila-Nova et al., 2011; Cota et al., 2012; 
Ramírez-Macías et al., 2012; Vila-Nova et al., 2012; Santos et al., 2013).

Members of the family Myrtaceae are ubiquitous in Brazil, and the presence of around 1000 species in discrete biomes, principally the Atlantic forest, restinga and cerrado, suggests an ecological importance. Myrciaria is a genus of large shrubs and small trees belonging to the myrtle family, and various species are used in traditional medicine (Souza, Lorenzi, 2012).

The shrub Myrciaria plinioides D. Legrand, popularly known as camboim, cambuim or cambui, is native to the state of Rio Grande do Sul in southern Brazil. Despite the medicinal potential of this species, very few reports are available concerning its pharmacological activities. For example, tea prepared from the leaves of Myrciaria tenella, popularly known as vassourinha, is employed in the Amazonian region as a post-partum uterine cleansing agent (Coelho-Ferreira, 2009), while the volatile oil obtained from leaves of this species is rich in $\alpha$-pinene and $\beta$-pinene and exhibits antimicrobial activity against Enterobacter spp. and Shigella flexneri (Schneider et al., 2008). Additionally, the leaves and trunk bark of M. cauliflora (popular name jabuticaba) are used to treat diarrhoea, asthma, and throat inflammation (Albuquerque et al., 2007), while ethanolic extracts of the leaves exhibit inhibitory action against Candida and Streptococcus cultures derived from dental plaque (Carvalho et al., 2009; Diniz et al., 2010). Of particular interest is the report (Ruiz et al., 2011) that the edible fruits of M. dubia are employed by Indigenous and Mestizo populations living on the banks of the Nanay river in the Loreto region of Peru as a traditional remedy for the treatment of malaria, which is also a neglected protozoan infection.

In consideration of the above, we have assessed the in vitro activities of essential oil of $M$. plinioides against Leishmania infantum (syn. L. chagasi), which is the causal agent of visceral leishmaniasis, and against L. amazonensis, a species that has been associated with various clinical forms of the disease including cutaneous, mucosa, diffuse cutaneous and visceral leishmaniasis (Leon et al., 1990). In addition, we have determined the composition of the essential oil derived from this native Brazilian species.

\section{MATERIAL AND METHODS}

\section{Plant material}

Leaves of Myrciaria plinioides D. Legrand were collected in Lajeado, RS, Brazil during July 2012. The plants were authenticated by the botanist Dr. Elisete Maria de Freitas (Centro Universitário UNIVATES) and a voucher specimen was deposited at the Herbário do Vale do Taquari, Museu de Ciências Naturais UNIVATES under the registration number HVAT1066.

\section{Preparation of essential oil}

Fresh leaves ( $200 \mathrm{~g}$ ) of M. plinioides were subjected to hydro-distillation for $3.5 \mathrm{~h}$ in a Clevenger-type apparatus. The essential oil (MPEO) was dried over anhydrous sodium sulphate, transferred to amber glass bottles and stored at $-20^{\circ} \mathrm{C}$, until required for chemical analysis and bioassay.

\section{Chemical analysis of the essential oil}

Samples of MPEO were analysed by gas chromatography coupled to mass spectrometry (GC-MS) at the Instrumental Analysis Laboratory, Food Processing Development Centre - FPDC, Univates. Analyses were performed on a Shimadzu GC2010 Plus system, comprising a model AOC5000 Plus auto injector and a model QP2110 Ultra mass detector, using a Restek Rtx ${ }^{\circledR}-5 \mathrm{MS}$ fused silica capillary column ( $30 \mathrm{~m}$ x $0.25 \mathrm{~mm}$ i.d.; $0.25 \mu \mathrm{m}$ film thickness). The chromatographic conditions were: carrier gas - helium at a flow rate of $1.00 \mathrm{~mL} / \mathrm{min}$; oven temperature - initially at $50{ }^{\circ} \mathrm{C}$ and increased at $4{ }^{\circ} \mathrm{C} / \mathrm{min}$ to $290{ }^{\circ} \mathrm{C}$; injector temperature $-240{ }^{\circ} \mathrm{C}$; injection mode - split with 1:20 ratio and $3 \mathrm{~mL} / \mathrm{min}$ purge; MS interface temperature $-280{ }^{\circ} \mathrm{C}$; ion source temperature $-260{ }^{\circ} \mathrm{C}$; ionisation energy $-70 \mathrm{eV}$. Oil samples $(15 \mathrm{mg})$ were dissolved in $1.5 \mathrm{~mL}$ of purified ethyl acetate and aliquots in the order of $1 \mu \mathrm{L}$ were injected for analysis. GC analyses with flame ionisation detection (FID) were carried out using an Agilent J \& W HP-5 MS column (30 m x $0.25 \mathrm{~mm}$ i.d.; $0.25 \mu \mathrm{m}$ film thickness) with helium as carrier gas, an FID temperature of $260^{\circ} \mathrm{C}$ and the oven temperature program as described for the GC-MS procedure.

Separated components were identified initially from their Kováts retention indices (RI), determined by reference to a series of $n$-alkanes, and their identities confirmed by comparison of mass spectral data with those obtained using pure standards together with values quoted in the literature (Adams, 2009) and those stored in the Wiley 8 and NIST11 spectral libraries of the analytical system. The relative compositions of the oils were calculated from the peak areas (uncorrected for specific response factors) of the separated components. 


\section{Cultivation of Leishmania promastigotes}

Promastigotes of L. amazonensis MHOM/BR/77/ LTB0016 were grown at $26^{\circ} \mathrm{C}$ in Schneider's Drosophila medium (Sigma-Aldrich) supplemented with $10 \%(\mathrm{v} / \mathrm{v})$ heat-inactivated fetal calf serum (FCS) and adjusted to $\mathrm{pH}$ 7.2. Promastigotes of $L$. infantum MCAN/BR/97/P142 were cultivated at the same temperature and $\mathrm{pH}$, but in this case the medium was supplemented with $20 \%(\mathrm{v} / \mathrm{v}) \mathrm{FCS}$, $2 \%(\mathrm{v} / \mathrm{v})$ human urine, $100 \mu \mathrm{g} / \mathrm{mL}$ streptomycin and 100 $\mathrm{U} / \mathrm{mL}$ penicillin. Promastigotes were harvested on day 4 , when the percentage of infective metacyclic forms was found to be high, and counted in a Neubauer chamber. Parasite suspensions were adjusted to a concentration of $1 \times 10^{7}$ promastigotes $/ \mathrm{mL}$ using the supernatant of the respective culture as diluent.

\section{Determination of antileishmanial activity in vitro}

Appropriate amounts of MPEO or pentamidine isethionate (as reference drug) $\left(\right.$ Sideron $\left.^{\circledR}\right)$ were dissolved in aqueous dimethyl sulphoxide (DMSO; $10 \mathrm{mg} / \mathrm{mL}$ ) to yield solutions containing analytes in the concentration range of 0.156 to $80 \mu \mathrm{g} / \mathrm{mL}$. The level of DMSO in each assay solution was below $1.4 \%$, which is the highest concentration that is not hazardous to the parasites.

Suspensions of late log phase promastigotes suspended in Schneider's Drosophila medium were seeded in Corning TM 96-well flat bottom tissue culture tested plates $\left(1 \times 10^{7}\right.$ promastigotes $/ 200 \mu \mathrm{L} /$ well $)$. Aliquots of freshly prepared MPEO and pentamidine were added to the wells and the plates were incubated for $24 \mathrm{~h}$ at $26{ }^{\circ} \mathrm{C}$. Promastigote viability was evaluated using a modified version of the dye-reduction assay employing 3-(4,5-dimethylthiazol-2-yl)-2,5-diphenyl tetrazolium bromide (MTT) (Dutta et al., 2005). Briefly, MTT reagent was added to each well and incubation was continued in the dark for an additional $4 \mathrm{~h}$. After this time, an $80 \mu \mathrm{L}$ aliquot of DMSO was added to each well and the optical density of the assay solution was determined at $570 \mathrm{~nm}$ using a BioTek $\mu$ Quant ${ }^{\mathrm{TM}}$ microplate spectrophotometer. The specific absorbance associated with the formazan soproduced was determined by subtracting the background absorbance from the total absorbance, and the mean percentage viability was calculated from:

\footnotetext{
Mean specific absorbance of treated parasites

Mean specific absorbance

of untreated parasites
}

Values for $\mathrm{IC}_{50}$, i.e. the concentration that inhibited parasite growth by $50 \%$, were determined.

\section{Assessment of cytotoxicity}

Peritoneal macrophages from BALB/c mice were obtained by using the lavage technique, counted in a Neubauer chamber and adjusted to a concentration of $2 \times 10^{6}$ cells $/ \mathrm{mL}$. Macrophages were transferred to Corning 96-well flat bottom tissue culture tested plates and incubated for $24 \mathrm{~h}$ at $37^{\circ} \mathrm{C}$ under a $5 \% \mathrm{CO}_{2}$ atmosphere. Freshly prepared solutions, in aqueous DMSO, containing MPOE or pentamidine isethionate at concentrations range 0.156 to $80 \mu \mathrm{g} / \mathrm{mL}$ were then added to the wells. Macrophage viability was evaluated using a modified version of the dye-reduction assay employing MTT. In order to assess macrophage viability, $22 \mu \mathrm{L}$ of MTT solution $(5 \mathrm{mg} / \mathrm{mL})$ was added to each well and the plates were incubated for an additional $2 \mathrm{~h}$. After this time, an $80 \mu \mathrm{L}$ aliquot of DMSO was added to each well and the optical density of the assay solution was determined at $540 \mathrm{~nm}$ using a BioTek $\mu$ Quant ${ }^{\mathrm{TM}}$ microplate spectrophotometer. This study was approved for The Animal Ethics Committee of the Institute Oswaldo Cruz/IOC - FIOCRUZ (license number L-026/2015).

\section{Statistical analysis}

Assays were carried out in three independent experiments and each was performed in triplicate. Values of $\mathrm{IC}_{50}$ and $\mathrm{CC}_{50}$ were determined by logarithmic regression analysis using GraphPrism 5 software. Values for in vitro antileishmanial activity and in vitro cytotoxicity were expressed as mean \pm standard deviation. The significant differences between samples were evaluated by analysis of variance (ANOVA) and the Tukey test using BioEstat 5.0 software with the alpha level set at 0.05 .

\section{RESULTS AND DISCUSSION}

\section{Analysis of the essential oil from fresh leaves of M. plinioides}

The yield of essential oil obtained from fresh leaves of $M$. plinioides was $0.05 \%(\mathrm{w} / \mathrm{w})$. According to the GC analyses, the oil comprised 66 components (Table I) and was particularly rich in oxygenated sesquiterpenes $(82.66 \%)$ and sesquiterpene hydrocarbons $(11.05 \%)$. The principal volatile components of the oil were the sesquiterpenes spathulenol $(21.12 \%)$, caryophyllene oxide (15.20\%), $\alpha$-isolongifolan-7-ol (9.84\%), mustakone 
(5.60\%), $\alpha$-cadinol (5.40\%), cis-isolongifolanone (3.38\%) and $\alpha$-copaene (3.27\%).

Members of the family Myrtaceae are commonly rich in essential oils, many of which possess biological activity (Tietbohl et al., 2012; Borges, Conceição, Silveira, 2014). In the case of $M$. floribunda, popularly known as camboin amarelo, monoterpenes predominated in the oils derived from leaves and flowers, with 1,8-cineole as the major component accounting for $38.4 \%$ of the leaf oil and $22.8 \%$ of the flower oil (Tietbohl et al., 2012). In contrast, the stem oil contained mainly sesquiterpenes, of which $(2 E, 6 E)$-farnesyl acetate represented the major component accounting for $19.9 \%$ of the oil.

Oxygenated sesquiterpenes have been identified as major constituents of leaf oils from a number of Myrciaria species (Apel et al., 2006). Thus, the oil of M. cauliflora, similar to that of M. plinioides, contained mainly spathulenol (27.2\%) and caryophyllene oxide (21.6\%), while $\beta$-caryophyllene, caryophyllene oxide and spathulenol predominated in the essential oil of M. edulis. Conversely, the major components of $M$. trunciflora leaf oil were globulol, bicyclogermacrene and $\gamma$-muurolene, while the essential oil of $M$. cordifolia was rich in $\alpha$-bisabolol oxide A, $\alpha$-bisabolol oxide B, $\alpha$-bisabolol and $\beta$-caryophyllene. The oxygenated sesquiterpenes spathulenol and caryophyllene oxide have been identified as major constituents of the essential oils of other members of the Myrtaceae, including Eugenia brasiliensis (Magina et al., 2009), E. calycina (Sousa et al., 2015), Eucalyptus camaldulensis (Verdeguer et al., 2009) and Callistemon citrinus (Petronilho et al., 2013).

\section{In vitro antileishmanial activity and cytotoxicity of the essential oil from fresh leaves of M. plinioides}

The essential oil derived from leaves of $M$. plinioides was effective against $L$. amazonensis promastigotes (Table II) and presented $\mathrm{IC}_{50}$ value of $14.16 \pm 7.40 \mu \mathrm{g} / \mathrm{mL}$, while the standard drug pentamidine isethionate presented $\mathrm{IC}_{50}$ value of $23.22 \pm 9.04 \mu \mathrm{g} / \mathrm{mL}$. However, activity against $L$. infantum promastigotes were less pronounced, presented an $\mathrm{IC}_{50}$ value of $101.50 \pm 5.78 \mu \mathrm{g} / \mathrm{mL}$ (Table II).

American tegumentary leishmaniasis (ATL) affects populations in various regions of the world, including an area extending from southern USA to northern Argentina, with the exception of Chile and Uruguay. The disease can present with diverse clinical forms described as cutaneous, diffuse cutaneous or mucocutaneous. Moreover, ATL can cause injury way beyond its deforming effects, thereby raising issues concerning possible psychological damage and, consequently, social and economic losses (Amato Neto et al., 2008; Garcia et al., 2011).

Antileishmanial activity has been demonstrated for essential oils from a number of plant species including Lippia origanoides (Escobar et al., 2010), L. sidoides (Medeiros et al., 2011; Farias-Junior et al., 2012) and Lantana camara (Machado et al., 2012). In the case of M. plinioides, it is likely that the antileishmanial activity of the leaf oil is associated with the presence of the sesquiterpenes spathulenol and caryophyllene oxide, which represent $36.32 \%$ of the total components.

In this context, various studies have demonstrated that terpenes can cause alterations in the mitochondrial membrane potential, modification of the redox index, inhibition of cellular isoprenoid biosynthesis and changes in the plasma membrane (Santos et al., 2008; Rodrigues et al., 2013; Monzote et al., 2014). According to Oliveira et al. (2014), the essential oil of Bocageopsis multiflora is also rich in spathulenol and exhibits in vitro antileishmanial activity against promastigotes of Leishmania amazonensis. Additionally, spathulenol and caryophyllene oxide have been identified as the principle components of the essential oil of Piper angustifolium (Bosquiroli et al., 2015), which also exhibits significant in vitro antileishmanial activity against $L$. infantum amastigotes.

Monzote et al. (2014) carried out a comparative study of the essential oil of Chenopodium ambrosioides and its major constituents, namely ascaridole, carvacrol and caryophyllene oxide, and found that the natural mixture of the oil was potentially more active than the isolated components. Caryophyllene oxide, for example, exhibited non-specific activity and presented similar $\mathrm{IC}_{50}$ values against L. amazonensis and macrophages. Santin et al. (2009) reported an analogous situation for the essential oil of Cymbopogon citratus in which the principal constituent, citral, exhibited greater toxicity than the natural oil mixture. These results demonstrate the importance of complementary studies to determine whether the leishmanicidal activity against Leishmania promastigotes and cytotoxicity observed for $M$. plinioides is related to a specific component or mixture thereof.

Pentamidine isethionate and other drugs used in the treatment of leishmaniasis are toxic and their application is limited owing to issues associated with high cost, acquired resistance, routes of administration and difficulties of adherence to treatment (Bucknerm Waters, Avery, 2012). The MPEO showed significant activity against $L$. amazonensis, and presented selectivity index (SI) of 6.60 (Table II). The activity against $L$. infantum promastigotas form of sample was less significant, besides that the SI data demonstrated considerable toxicity. 
TABLE I - Composition of the essential oil from fresh leaves of M. plinioides

\begin{tabular}{|c|c|c|c|c|c|c|c|}
\hline Compound & $\mathbf{R I}_{\text {EXP }}^{\mathrm{a}}$ & $\mathbf{R I}_{\text {LIT }}^{\mathrm{b}}$ & $\begin{array}{c}\text { Relative } \\
\text { composition } \\
(\%)\end{array}$ & Compound & $\mathbf{R I}_{\mathrm{EXP}}^{\mathrm{a}}$ & $\mathbf{R I}_{\text {LIT }}^{\mathrm{b}}$ & $\begin{array}{c}\text { Relative } \\
\text { composition } \\
\text { (\%) }\end{array}$ \\
\hline $\mathrm{NI}^{\mathrm{c}}$ & 1049 & - & 0.05 & Vulgarone B & 1663 & 1651 & 0.70 \\
\hline$\alpha$-Terpineol & 1194 & 1189 & 0.11 & $\alpha$-Cadinol & 1667 & 1654 & 5.40 \\
\hline$\alpha$-Ylangene & 1373 & 1375 & 0.08 & Selin-11-en-4- $\alpha$-ol & 1669 & 1659 & 0.63 \\
\hline$\alpha$-Copaene & 1378 & 1376 & 3.27 & cis-Calamenen-10-ol & 1670 & 1661 & 0.26 \\
\hline$\beta$-Bourbonene & 1386 & 1388 & 1.24 & 14-Hydroxy-(Z)-caryophyllene & 1673 & 1667 & 0.24 \\
\hline$\beta$-Elemene & 1394 & 1391 & 0.26 & trans-Calamenen-10-ol & 1677 & 1669 & 0.19 \\
\hline$\beta$-Ylangene & 1421 & 1421 & 0.09 & 14-Hydroxy-9-epi-(E)- & 1679 & 1669 & 0.22 \\
\hline$\beta$-Copaene & 1431 & 1432 & 0.10 & caryophyllene & & & \\
\hline Aromadendrene & 1440 & 1441 & 0.17 & Cadalene & 1682 & 1676 & 1.49 \\
\hline$\alpha$-Humulene & 1455 & 1455 & 0.08 & Mustakone & 1685 & 1677 & 5.60 \\
\hline allo-Aromadendrene & 1462 & 1460 & 0.83 & Khusinol & 1690 & 1680 & 1.60 \\
\hline$\gamma$-Muurolene & 1479 & 1480 & 0.67 & 5-neo-Cedranol & 1695 & 1685 & 0.36 \\
\hline cis-Eudesma-6,11-diene & 1487 & 1490 & 0.11 & Germacra-4(15), 5, & 1702 & 1686 & 0.19 \\
\hline trans-Muurola-4(14),5-diene & 1496 & 1494 & 0.10 & 10(14)-trien-1- $\alpha$-ol & & & \\
\hline$\alpha$-Muurolene & 1503 & 1500 & 0.31 & 10-nor-Calamenen-10-one & 1704 & 1702 & 0.45 \\
\hline$\delta$-Amorphene & 1522 & 1512 & 0.55 & Mayurone & 1707 & 1704 & 0.43 \\
\hline trans-Calamenene & 1535 & 1529 & 0.15 & E-Apritone & 1711 & 1708 & 0.24 \\
\hline$(E)-\gamma$-Bisabolene & 1554 & 1531 & 0.06 & Longifolol & 1716 & 1714 & 0.14 \\
\hline$\beta$-Vetivenene & 1559 & 1533 & 0.84 & $E$-Nerolidyl acetate & 1720 & 1717 & 1.70 \\
\hline Silphiperfol-5-en-3-ol B & 1575 & 1535 & 1.53 & iso-Longifolol & 1728 & 1729 & 0.60 \\
\hline Selina-3,7(11)-diene & 1595 & 1546 & 0.65 & Vetiselinenol & 1730 & 1731 & 0.10 \\
\hline 1-nor-Bourbonanone & 1601 & 1563 & 0.14 & Eremophilone & 1735 & 1736 & 0.78 \\
\hline Spathulenol & 1606 & 1578 & 21.12 & $E-\beta$-Santalol & 1741 & 1739 & 0.41 \\
\hline Caryophyllene oxide & 1610 & 1583 & 15.20 & 8- $\alpha$-11-Elemodiol & 1748 & 1747 & 0.33 \\
\hline$\beta$-Copaen-4- $\alpha$-ol & 1613 & 1591 & 1.25 & NI & 1751 & - & 0.15 \\
\hline Khusimone & 1617 & 1604 & 2.61 & $\alpha$-Bisabolol oxide A & 1753 & 1749 & 0.45 \\
\hline Curzerenone & 1619 & 1606 & 1.22 & $\beta$-Acoradienol & 1767 & 1763 & 0.64 \\
\hline$\beta$-Atlantol & 1623 & 1608 & 0.43 & $\beta$-Costol & 1772 & 1767 & 0.69 \\
\hline cis-Isolongifolanone & 1626 & 1613 & 3.38 & Khusinol acetate & 1820 & 1823 & 0.18 \\
\hline Isolongifolan-7- $\alpha$-ol & 1631 & 1619 & 9.84 & NI & 1839 & - & 0.43 \\
\hline Junenol & 1637 & 1619 & 0.82 & $8 S, 13$-Cedranediol & 1904 & 1897 & 0.22 \\
\hline 2,(7Z)-Bisaboladien-4-ol & 1642 & 1619 & 0.99 & Total constituents identified & & & 99.37 \\
\hline 1,10-Di-epi-cubenol & 1646 & 1619 & 2.13 & Oxygenated monoterpenes & & & 0.11 \\
\hline trans-Isolongifolanone & 1649 & 1626 & 0.24 & Sesquiterpene hydrocarbons & & & 11.05 \\
\hline$\beta$-Cedren-9-one & 1652 & 1631 & 0.33 & Oxygenated sesquiterpenes & & & 82.66 \\
\hline epi- $\alpha$-Muurolol & 1657 & 1642 & 2.65 & \multirow{2}{*}{\multicolumn{4}{|c|}{$\begin{array}{l}{ }^{a} \text { Experimental retention Index. }{ }^{b} \text { Literature retention Index } \\
\text { (Adams, 2007). }{ }^{c} \text { Not identified. }\end{array}$}} \\
\hline$\alpha$-Muurolol & 1661 & 1646 & 1.54 & & & & \\
\hline
\end{tabular}

The results obtained in this study reveal that the MPEO is promising as a source for new antileishmanial agents against $L$. amazonensis. However, more studies are necessary in order to determine the constituents 
TABLE II - $\mathrm{IC}_{50}(\mu \mathrm{g} / \mathrm{mL})$ value of essential oil of M. plinioides against promastigotes of L. amazonensis and L. infantum and $\mathrm{CC}_{50}$ $(\mu \mathrm{g} / \mathrm{mL})$ value of cytoxicity against murine peritoneal macrophages.

\begin{tabular}{|c|c|c|c|c|}
\hline \multirow[t]{2}{*}{ Extract } & \multicolumn{2}{|c|}{$\begin{array}{l}\text { Antiparasitic Activity } \\
\operatorname{IC}_{50}(\mu \mathrm{g} / \mathrm{mL})\end{array}$} & \multirow{2}{*}{$\begin{array}{c}\text { Toxicity } \\
\mathrm{CC}_{50}(\boldsymbol{\mu g} / \mathrm{mL}) \\
\text { Macrophages }\end{array}$} & \multirow[t]{2}{*}{ SI } \\
\hline & L. amazonensis & L. infantum & & \\
\hline MPEO & $14.16 \pm 7.40^{\mathrm{a}}$ & $101.50 \pm 5.78^{a}$ & $93.50 \pm 9.10$ & 6.60 \\
\hline Pentamidine ${ }^{*}$ & $23.22 \pm 9.04^{\mathrm{a}}$ & $34.20 \pm 2.50^{\mathrm{b}}$ & $61.21 \pm 1.40$ & 2.63 \\
\hline
\end{tabular}

*Reference drug. ** Selective Index: ratio $\mathrm{CC}_{50} / \mathrm{IC}_{50}$ (L. amazonensis). Data are expressed as mean values \pm standard error. Within each column, values followed by dissimilar upper case superscript letters are statistically different $(p>0.05)$.

responsible for the antileishmanial activity and the mechanism of action involved. It stands out that the assay against promastigote forms is a preliminary screening to identify possible novel antileishmanial compounds, as it is a low cost and easy to handle method like in amastigotes (Siqueira-Neto et al., 2010). Even so, it is essential to evaluate the activity of MPEO against amastigote forms.

\section{ACKNOWLEDGMENTS}

The authors acknowledge to Fundação de Amparo à Pesquisa do Estado do Rio Grande do Sul (FAPERGS) and Conselho Nacional de Desenvolvimento Científico e Tecnológico (CNPq; PRONEX-10/0029-0).

\section{REFERENCES}

Adams RP. Identification of Essential Oil Components by Gas Chromatography/Mass Spectrometry. $4^{\text {th }}$ ed. Illinois: Allured Publishing Corporation; 2009. 804 p.

Albuquerque UP, Medeiros PM, Almeida ALS, Monteiro JM, Lins Neto EMF, Melo JG, et al. Medicinal plants of the caatinga (semi-arid) vegetation of NE Brazil: A quantitative approach. J Ethnopharmacol. 2007;114(3):325-54.

Amato Neto V, Amato VS, Gryschek RCB, Tuon FF. Parasitologia: uma abordagem clínica. Rio de Janeiro: Elsevier; 2008. p. 103-110.

Apel MA, Sobral M, Zuanazzi JA, Henriques AT. Essential oil composition of four Plinia species (Myrtaceae). Flavour Frag J. 2006;21(3):565-7.

Borges LL, Conceição EC, Silveira D. Active compounds and medicinal properties of Myrciaria genus. Food Chem. 2014;153:224-33.
Bosquiroli LSS, Demarque DP, Rizk YS, Cunha MC, Marques MCS, Matos MFC, Kadri MCT, Carollo CA, Arruda CCP. In vitro anti-Leishmania infantum activity of essential oil from Piper angustifolium. Rev Bras Farmacogn. 2015;25(2):124-128.

Buckner FS, Waters NC, Avery VM. Recent highlights in antiprotozoan drug development and resistance research. Int J Parasitol Drugs Drug Resist. 2012;2:230-5.

Carvalho CM, Macedo-Costa MR, Pereira MSV, Higino JS, Carvalho LFPC, Costa LJ. Efeito antimicrobiano in vitro do extrato de jabuticaba [Myrciaria cauliflora (Mart.)O.Berg.] sobre Streptococcus da cavidade oral. Rev Bras Plantas Med. 2009;11(1):79-83.

Coelho-Ferreira M. Medicinal knowledge and plant utilization in an Amazonian coastal community of Marudá, Pará State (Brazil). J Ethnopharmacol. 2009;126(1):159-75.

Cota BB, Siqueira EP, Oliveira DM, Alves TMA, Sobral MEG, Rabello A, et al. Chemical constituents and leishmanicidal activity from leaves of Kielmeyera variabilis. Rev Bras Farmacogn. 2012;22(6):1253-8.

Diniz DN, Macêdo-Costa MR, Pereira MSV, Pereira JV, Higino JS. Efeito antifúngico in vitro do extrato da folha e do caule de Myrciaria cauliflora berg. sobre microrganismos orais. Rev Odontol UNESP. 2010;39(3):151-6.

Dutta A, Bandyopadhyay S, Mandal C, Chatterjee M. Development of a modified MTT assay for screening antimonial resistant field isolates of Indian visceral leishmaniasis. Parasitol Int. 2005;54(2):119-22.

Escobar P, Leal SM, Herrera LV, Martinez JR, Stashenko E. Chemical composition and antiprotozoal activities of Colombian Lippia spp essential oils and their major components. Mem Inst Oswaldo Cruz. 2010;105(2):184-90. 
Farias-Junior PA, Rios MC, Moura TA, Almeida RP, Alves $\mathrm{PB}$, Blank AF, et al. Leishmanicidal activity of carvacrolrich essential oil from Lippia sidoides Cham. Biol Res. 2012;45(4):399-402.

Freitas-Junior LH, Chatelain E, Kim HA, Siqueira-Neto JL. Visceral leishmaniasis treatment: What do we have, what do we need and how to deliver it? Int J Parasitol Drugs Drug Resist. 2012;2:11-9.

Garcia LP, Magalhães LCG, Aurea AP, Santos CF, Almeida RF. Epidemiologia das doenças negligenciadas no Brasil e gastos federais com medicamentos - Texto para Discussão. $1^{\text {a }}$ ed. Brasília: Instituto de Pesquisa Econômica Aplicada (IPEA); 2011.

Leon LL, Machado GM, Paes LE, Grimaldi Jr. G. Antigenic differences of Leishmania amazonensis isolates causing diffuse cutaneous leishmaniasis. Trans R Soc Trop Med Hyg. 1990;84:678-80.

Machado RRP, Valente Junior W, Lesche B, Coimbra ES, Souza NB, Abramo C, et al. Essential oil from leaves of Lantana camara: a potential source of medicine against leishmaniasis. Rev Bras Farmacogn. 2012;22(5):1011-7.

Magina MDA, Dalmarco EM, Wisniewski Jr A, Simionatto EL, Pizzolatti JB, Brighente MG. Chemical composition and antibacterial activity of essential oils of Eugenia species. J Nat Med. 2009;63(3):345-50.

Medeiros MGF, Silva AC, Citó AMGL, Borges AR, Lima $\mathrm{SG}$, Lopes AJD, et al. In vitro antileishmanial activity and cytotoxicity of essential oil from Lippia sidoides Cham. Parasitol Int. 2011;60(3):237-41.

Monzote L, García M, Pastor J, Gil L, Scull R, Maes L, et al. Essential oil from Chenopodium ambrosioides and main components: Activity against Leishmania, their mitochondria and other microorganisms. Exp Parasitol. 2014;136:20-6.

Oliveira ACM, Fontana A, Negrini TC, Nogueira MNM, Bedran TBL, Andrade CR, et al. Emprego do óleo de Melaleuca alternifolia Cheel (Myrtaceae) na odontologia: perspectivas quanto à utilização como antimicrobiano alternativo às doenças infecciosas de origem bucal. Rev Bras Plantas Med. 2011;13(4):492-9.

Oliveira ESC, Amaral ACF, Lima EJ, Silva JRA. Chemical composition and biological activities of Bocageopsis multiflora essential oil. J Essen Oil Res. 2014;26(3):161-5.
Petronilho S, Rocha SM, Ramírez-Chávez E, Molina-Torres J, Rios-Chavez P. Assessment of the terpenic profile of Callistemon citrinus (Curtis) Skeels from Mexico. Ind Crops Prod. 2013;46:369-79.

Ramírez-Macías I, Marín C, Chahboun R, Olmo F, Messouri I, Huertas $\mathrm{O}$, et al. In vitro evaluation of new terpenoid derivatives against Leishmania infantum and Leishmania braziliensis. Mem Inst Oswaldo Cruz. 2012;107(3):370-6.

Rodrigues KAF, Amorim LV, Oliveira JMG, Dias CN, Moraes DFC, Andrade EHA, et al. Eugenia uniflora L. essential oil as a potential anti-Leishmania agent: effects on Leishmania amazonensis and possible mechanisms of action. Evid Based Complement Alternat Med. 2013;2013:279726.

Ruiz L, Ruiz L, Maco M, Cobos M, Gutierrez-Choquevilca AL, Roumy V. Plants used by native Amazonian groups from the Nanay River (Peru) for the treatment of malaria. J Ethnopharmacol. 2011;133(2):917-21.

Santin MR, dos Santos AO, Nakamura CV, Prado B, Piloto IC, Ueda-Nakamura T. In vitro activity of the essential oil of Cymbopogon citratus and its major component (citral) on Leishmania amazonensis. Parasitol Res. 2009;105(6):1489-96.

Santos AO, Ueda-Nakamura T, Dias Filho BP, Veiga Junior VF, Pinto AC, Nakamura CV. Effect of Brazilian copaiba oils on Leishmania amazonensis. J Ethnopharmacol. 2008;120(2):2048.

Santos AOD, Izumi E, Ueda-Nakamura T, Dias-Filho BP, VeigaJúnior VF, Nakamura CV. Antileishmanial activity of diterpene acids in copaiba oil. Mem Inst Oswaldo Cruz. 2013;108(1):5964.

Schneider NFZ, Moura NF, Colpo T, Marins K, Marangoni C, Flach A. Estudo dos compostos voláteis e atividade antimicrobiana da Myrciaria tenella (cambuí). Rev Bras Farm. 2008;89(2):131-3.

Siqueira-Neto JL, Song O, Oh H, Sohn J, Yang G, Nam J, et al. Antileishmanial high-throughput drug screening reveals drug candidates with new scaffolds. PLoS Negl Trop Dis. 2010;4(5):e675.

Sousa RMF, Morais SAL, Vieira RBK, Napolitano DR, Guzman VB, Moraes TS, et al. Chemical composition, cytotoxic, and antibacterial activity of the essential oil from Eugenia calycina Cambess. leaves against oral bacteria. Ind Crops and Prod. 2015;65:71-8. 
Souza VC, Lorenzi H. Botânica sistemática: guia ilustrado para identificação das famílias de fanerógamas nativas e exóticas no Brasil, baseado em APG III, third ed. Nova Odessa: Instituto Plantarum; 2012. p. 428-429.

Tietbohl LAC, Lima BG, Fernandes CP, Santos MG, Silva FEB, Denardin ELG, et al. Comparative study and anticholinesterasic evaluation of essential oils from leaves, stems and flowers of Myrciaria floribunda (H.West ex Willd.) O. Berg. Lat Am J Pharm. 2012;31(4):637-41.

Verdeguer M, Amparo Blázquez M, Boira H. Phytotoxic effects of Lantana camara, Eucalyptus camaldulensis and Eriocephalus africanus essential oils in weeds of Mediterranean summer crops. Biochem Syst and Ecol. 2009;37(4):362-9.
Vila-Nova NS, Morais SM, Falcão MJC, Machado LKA, Beviláqua CML, Costa I, et al. Leishmanicidal activity and cytotoxicity of compounds from two Annonacea species cultivated in Northeastern Brazil. Rev Soc Bras Med Trop. 2011;44(5):567-71.

Vila-Nova NS, Morais SM, Falcão MJC, Beviláqua CML, Rondon FCM, Wilson ME, et al. Leishmanicidal and cholinesterase inhibiting activities of phenolic compounds of Dimorphandra gardneriana and Platymiscium floribundum, native plants from Caatinga biome. Pesquisa Vet Brasil. 2012;32(11):1164-8.

Received for publication on $12^{\text {th }}$ January 2018 Accepted for publication on $14^{\text {th }}$ August 2018 